\title{
Respon Masyarakat Terhadap Penyuluhan Pemanfaatan Limbah Organik Menjadi Kompos dengan Penambahan Biourine di Desa Cangkring, Kecamatan Plumpang, Kabupaten Tuban
}

\author{
Lilik Mawartiningsih \\ Universitas PGRI Ronggolawe Tuban
}

\author{
Imas Cintamulya \\ Universitas PGRI Ronggolawe Tuban
}

Tabitha Sri Hartati W

Universitas PGRI Ronggolawe Tuban

\begin{abstract}
Garbage is a material that is no longer used in the form of solid or liquid. Garbage will cause various problems if not handled properly. Marine debris is a source of marine pollution and a global cause of various ecological impacts. Inorganic waste is waste that is difficult to decompose, such as plastic bottles and cups for drinks, paper, wood and so on. Organic waste, rubbish that quickly decays, such as fruit skins, vegetables, food scraps, fruits, dry leaves. This can be processed into compost. Composting can be done using biourine. The aim of this training is to know the dangers of organic waste and utilize organic waste into compost with biourine assistance. The method used is the socialization of the dangers of organic waste, training and workshops. training participants regarding the materials used in the training are widely available in the environment where they live, especially EM4 materials, but they do not know their use. The advantages of this training are compost from organic waste with the help of biourine can accelerate plant growth and also this fertilizer is environmentally friendly. However, fertilizer it has a drawback that is the manufacturing process requires long time.
\end{abstract}

Keywords: Compost; Biourine; EM4

\section{Abstrak}

Sampah adalah bahan yang tidak digunakan lagi yang berbentuk padat maupun cair.Sampah akan menimbulkan berbagai masalah jika tidak ditangani secara baik Sampah-sampah di laut merupakan salah satu sumber pencemaran laut dan sebagai penyebab global berbagai dampak ekologis. sampah anorganik merupakan sampah yang sulit membusuk,seperti botol dan gelas plastik minuman,kertas,kayu dan sebagainya Sampah organik ,sampah yang cepat membusuk,seperti kulit buah-buahan,sayuran,sisa makanan,buah-buahan,daun -daun kering.Sampah organik ini dapat diolah menjadi kompos.Pengomposan dapat dilakukan dengan menggunakan biourine.Tujuan dari pelatihan ini mengetahui bahaya sampah organik dan memanfaatkan sampah organik menjadi kompos dengan bamtuan biourine.Metode yang digunakan adalah sosialisasi bahaya sampah organik, pelatihan dan worshop.Kesipulan dari pelatihan ini dari tanggapan peserta pelatihan mengenai bahan yang digunakan dalam pelatihan banyak tersedia di lingkungan tempat tinggal mereka,terutama bahan EM4,tetapi mereka tidak tahu penggunaannya.Keunggulan pelatihan ini,kompos dari sampah organik dengan bantuan biourine dapat mempercepat pertumbuhan tanaman dan juga pupuk ini ramah lingkungan.Namun pupuk ini memiliki kekurangan yaitu proses pembuatanya membutuhkan waktu yang lama.

Kata kunci: Kompos; Biourine; EM4

\section{Pendahuluan}

Sampah merupakan material sisa yang sudah tidak digunakan dan sesuatu yang harus dibuang atau harus didaur ulang yang berasal dari hasil kegiatan manusia. Sampah yang dihasilkan oleh manusia adalah sampah organik dan sampah anorganik. Menurut definisi World Health Organization (WHO) sampah adalah sesuatu yang tidak digunakan, tidak dipakai, tidak 
disenangi atau sesuatu yang dibuang yang berasal dari kegiatan manusia dan tidak terjadi dengan sendirinya [1].

Menurut Kementerian Lingkungan Hidup dan Kehutanan, pertambahan jumlah penduduk berbanding lurus dengan jumlah sampah yang dihasilkan. Hitungan secara kasar, dengan jumlah penduduk Indonesia saat ini lebih dari 250 juta orang, jika setiap orang menghasilkan sampah $0,7 \mathrm{~kg} /$ hari, maka timbunan sampah secara nasional mencapai $175 \mathrm{ribu}$ ton/hari atau setara dengan 64 juta ton/tahun. Adapun persentase sampah organik seperti sisa makanan, sayuran, buah-buahan, kertas, kayu mencapai 65,05\%. Sedangkan sampah nonorganik seperti plastik, styrofoam, dan besi, sekitar 34,95\% [2]

Desa cangkring kecamatan Plumpang Kabupaten Tuban merupakan desa yang sudah mengembangkan pengomposan secara organik, namun ada beberapa kendala yang dialami masyarakat dalam praktik pembuatan kompos secara organik. Salah satunya adalah faktor pembatas pengomposan sehingga pupuk organik yang dihasilkan kurang maksimal.

Faktor-faktor yang mempengaruhi pengomposan antara lain : kelembaban, konsentarasi oksigen, temperatur, perbandingan $\mathrm{C} / \mathrm{N}$, derajat keasaman $(\mathrm{pH})$, ukuran bahan.Mikroorganisme dapat bekerja dengan kelembaban sekitar 40-60\%. Kondisi tersebut perlu dijaga agar mikroorganisme bekerja optimal. Kebutuhan oksigen dalam pembuatan kompos yakni berkisar antara $10-18 \%$. Temperatur optimum yang dibutuhkan mikroorganisme untuk merombak bahan adalah $35-55^{\circ} \mathrm{C}$. Perbandingan $\mathrm{C} / \mathrm{N}$ yang optimum untuk proses pengomposan adalah berkisar antara 25-25.Derajat keasaman yang terbaik untuk proses pengomposan adalah pada kondisi $\mathrm{pH}$ netral yakni berkisar antara 6-8. Ukuran bahan yang dianjurkan pada pengomposan aerobik berkisar antara 1-7,5 $\mathrm{cm} \mathrm{[3].}$

Pengolahan sampah organik untuk keperluan pembuatan kompos dapat dilakukan secara sederhana, yaitu dengan menggunakan teknologi komposter yang terbuat dari tong atau ember. Komposter itu sendiri dapat bersifat aerob, anaerob dan semi anaerob. Secara alami bahanbahan organik akan mengalami penguraian di alam dengan bantuan mikroba maupun biota tanah lainnya.

Proses pengomposan adalah proses dekomposisi materi organik menjadi pupuk kompos melalui reaksi biologis mikroorganisme secara aerobik dalam kondisi terkendali. Pengomposan sendiri merupakan proses penguraian senyawa-senyawa yang terkandung dalam sisa-sisa bahan organik (seperti jerami, daun-daunan, sampah rumah tangga, dan sebagainya) dengan suatu perlakuan khusus. Hampir semua bahan yang pernah hidup, tanaman atau hewan akan membusuk dalam tumpukan kompos [4].

Kompos sebagai hasil dari pengomposan dan merupakan salah satu pupuk organik yang memiliki fungsi penting terutama dalam bidang pertanian antara lain : Pupuk organik mengandung unsur hara makro dan mikro.Pupuk organik dapat memperbaiki struktur tanah.Meningkatkan daya serap tanah terhadap air dan zat hara, memperbesar daya ikat tanah berpasir.Memperbaiki drainase dan tata udara di dalam tanah.Membantu proses pelapukan dalam tanah.Tanaman yang menggunakan pupuk organik lebih tahan terhadap penyakit. Proses pembuatan kompos berlangsung dengan menjaga keseimbangan kandungan nutrien, kadar air, $\mathrm{pH}$, temperatur dan aerasi yang optimal melalui penyiraman dan pembalikan. Pada tahap awal proses pengkomposan, temperatur kompos akan mencapai 65 - 70C sehingga organisma patogen, seperti bakteri, virus dan parasit, bibit penyakit tanaman serta bibit gulma yang berada pada limbah yang dikomposkan akan mati. Dan pada kondisi tersebut gas-gas yang berbahaya dan baunya menyengat tidak akan muncul. Proses pengkomposan umumnya berakhir setelah 6 sampai 7 minggu yang ditandai dengan tercapainya suhu terendah yang konstan dan kestabilan materi [3].

Pupuk organik cair merupakan larutan dari pembusukan bahan-bahan organik yang berasal dari sisa tanaman dan kotoran hewan yang memiliki kandungan unsur hara. Kelebihan dari pupuk organik ini adalah cepat mengatasi defisiensi hara dan mampu menyediakan hara secara cepat. Selain itu, pupuk organik cair tidak merusak tanah dan tanaman, meskipun pupuk 
organik cair ini sering digunakan.Pupuk organik cair memiliki juga bahan pengikat, sehingga larutan pupuk yang diberikan ke tanaman langsung diserap oleh tanaman. Pupuk Organik Cair (POC) dari urine sapi memiliki 3 fungsi utama yaitu sebagai pupuk cair bagi tanaman, sebagai zat pengatur tumbuh tanaman dan juga sebagai pestisida nabati [5].

Urine sapi merupakan kotoran ternak yang berbentuk cair. Selama ini urine sapi dibuang karena dianggap kotor juga bau, dan ternyata urine memiliki manfaat menjadi pupuk cair bagi tanaman. Kandungan makro antara kotoran hewan (kuda, kambing, sapi, babi, dan ayam) yang berbentuk padat dan cair memiliki perbedaan [6]. Kotoran padat kandungan nitrogen dan kaliumnya lebih kecil dibandingkan dengan jumlah persentase di dalam kotoran cair [7].

Pembuatan pupuk cair dari urine sapi cukup mudah dan tidak membutuhkan waktu lama, bahan mudah didapat, biayanya relatif murah, serta baik untuk tanaman. Pupuk cair ini mengandung protein yang menyuburkan tanah dan tanaman seperti padi, palawija, sayursayuran, buah-buahan dan bunga-bungaan [8].

Pupuk kandang cair (urine sapi) selain dapat bekerja cepat, juga mengandung hormon tertentu yang nyata dapat merangsang perkembangan tanaman. Dalam pupuk kandang cair kandungan $\mathrm{N}$ dan $\mathrm{K}$ cukup besar, sedangkan dalam pupuk kandang padat cukup kandungan $\mathrm{P}$ nya, sehingga hasil campuran antara keduanya di dalam kandang merupakan pupuk yang baik bagi pertumbuhan dan perkembangan tanaman [9].

Urine sapi merupakan limbah yang cair yang mengandung auksin dan dapat merangsang pertumbuhan akar. Auksin merupakan salah satu zat pengatur tumbuh (ZPT). Kadar zat pengatur tumbuh (ZPT) pada urin sapi dan disimpan selama 7 hari akan mempunyai kandungan auksin sebanyak 34 ppm dan giberellin sebanyak 268 ppm [10]. [11], mengatakan bahwa beberapa sifat urine sapi yang difermentasi terlihat adanya peningkatan komposisi jumlah dari unsur yang dikandung dibandingkan dengan yang tidak difermentasi dan juga urine sapi yang telah difermentasi dapat dijadikan sebagai nutrisi tanaman yang sebelumnya perlu dilakukan pengenceran. Tujuan dari pengabdian ini adalah untuk mengetahui respon masyarakat terhadap penyuluhan dan praktik pembuatan kompos dari limbah organik dengan bantuan Biourine. Evaluasi terhadap kompos organik dengan bantuan biourine merupakan keterbatasan dalam pengabdian ini.

\section{Metode Pelaksanaan}

Tahapan utama dalam pengabdian ini adalah sosialisasi dengan melakukan penyuluhan kepada warga desa terutama karang taruna tentang bahaya sampah dan pemanfaatan sampah khususnya sampah organik. Praktek pembuatan kompos yang dilakukan oleh TIM tentang cara pembuatan pupuk kompos dari limbah rumah tangga dengan bantuan biourine.

Metode pengomposan dalam pengabdian ini berdasarkan Utoma dan Nurdiana [12]. Adapun tahapan pertama yang dilakukan adalah Pencacahan. Pencacahan bertujuan untuk memudahkan makroorganisme dan mikroorganisme dalam mendekomposisi bahan organik yang digunakanalat yang akan digunakan adalah Mesin Grinding (mesin pencacah). Permukaan area yang lebih luas akan meningkatkan kontak antara mikroba dengan bahan dan proses dekomposisi akan berjalan lebih cepat. Ukuran partikel juga menentukan besarannya ruang antar bahan (porositas). Untuk meningkatkan luas permukaan dapat dilakukan dengan memperkecil ukuran partikel bahan tersebut. Pada pelaksanaan kompos akan melalui berbagai proses, yaitu: (1) Penimbangan. Proses penimbangan memerlukan beberapa alat seperti timbangan. Tujuan dari penimbangan ini agar perbandingan jumlah bahan dapat dipantau sebagai berat awal bahan organik yang digunakan. Berat total bahan organik yang digunakan adalah $100 \mathrm{~kg}$ pada tumpukan; (2) Penumpukan. Proses penumpukan bahan organik pada penelitian ini akan menggunakan metode Hot Composting, dengan suhu yang dihasilkan mencapai suhu termofilik yaitu pada suhu $50-60^{\circ} \mathrm{C}$ pada hari ke-4. Tumpukan yang digunakan yaitu tinggi 1,5 meter dan lebar 1,5 meter. Pada pembuatan kompos ini menggunakan perbandingan $60 \mathrm{~kg}$ daun kering 
dengan 40 kg sampah sayuran; (3) Pemantauan. Pemantauan bertujuan untuk mempertahankan parameter makro yang dapat menguntungkan dalam proses dekomposisi. Pada proses pemantauan yang akan lebih diukur adalah suhu,pH,kelembaban, dan aerasi; (4) Pembalikan. Proses pembalikan bertujuan untuk mempertahankan parameter yang dipantau, selain itu proses pembalikan akan menentukan kematangan dari kompos yang dibuat. Proses pembalikan dilakukan setiap 2 hari sekali dihitung dari proses pemeraman awal penumpukan hingga hari ke-4; dan (5) Pengayakan. Proses pengayakan ini bertujuan untuk memisahkan partikel kompos sesuai dengan ukurannya. Selain itu proses pengayakan akan merubah ukuran kompos mejadi lebih kecil.

Respon masyarakat terhadap penelitian melalui angket yang terdiri atas 5 butir pengalaman dan 6 butir tanggapan.

\section{Hasil dan Pembahasan}

Berdasarkan hasil penyebaran angket dijelaskan pada Tabel 1 dan Tabel 2 diketahui bahwa pengalaman peserta sebelum mengikuti pelatihan menunjukkan bahwa butir angket poin $180 \%$ tidak menggunakan pupuk kompos dan sedikitnya 20\% menggunakan pupuk kompos. Hal ini menunjukkan bahwa penggunaan pupuk kompos organik dan non organik terdapat perbedaan yang siginifikan. Penggunaan pupuk kimia lebih diminati karena pupuk lebih cepat diserap tanaman untuk proses pertumbuhan dan perkembangan, namun disisi lain menimbulkan dampak llingkungan yang signifikan, misalnya kebalnya hama dan mudahnya gulma tumbuh disekitar tanaman.

Tabel. 1. Pengalaman peserta sebelum mengikuti pelatihan

\begin{tabular}{cllc}
\hline No. & Komponen Pertanyaaan & \multicolumn{2}{c}{ Persentase (\%) } \\
\cline { 2 - 3 } & & Ya & Tidak \\
\hline 1 & $\begin{array}{l}\text { Apakah selama ini saudara sudah menggunakan pupuk kompos? } \\
\text { Apakah selama ini saudara sudah membuat sendiri pupuk } \\
\text { kompos? }\end{array}$ & 20 & 80 \\
& $\begin{array}{l}\text { Apakah saudara sudah pernah membuat pupuk kompos dari } \\
\text { sampah organik? }\end{array}$ & 60 & 40 \\
4 & $\begin{array}{l}\text { Apakah saudara sudah mengetahui tentang pupuk kompos dari } \\
\text { sampah organik dengan biourine? }\end{array}$ & 40 & 60 \\
& $\begin{array}{l}\text { Apakah selama ini saudara sudah puas dengan penggunaan } \\
\text { pupuk yang saudara gunakan untuk tanaman saudara? }\end{array}$ & 60 & 40 \\
\hline & Rata- rata & 44 & 56 \\
\hline
\end{tabular}

Angket poin 2 menunjukkan bahwa 40\% masyarakat sudah membuat pupuk organik sendiri namun karena faktor kecenderungan dalam menggunakan pupuk kimia maka penggunaan pupuk kimia berkisar $60 \%$. Penggunaan pupuk kimia. Masyarakat sudah membuat pupuk organik dari sampah organik menunjukkan rata-rata $60 \%$. Hal ini dipengaruhi bahwa implementasi pupuk organik di desa Cangkring masih dalam skal kecil sehingga masyarakat mengkombinasikan antara pupuk kompos dan pupuk kimia. Berdasar poin 4 menunjukkan bahwa rata-rata masyarakat mengetahui pupuk kompos dengan bantuan biourine sebesar $40 \%$ sedangkan masyarakat yang belum mengetahui sebesar $60 \%$. Berdasarkan poin 5 tingkat kepuasan antara pupuk kompos organik menunjukkan hasil yang tinggi rata-rata sebesar $60 \%$. Hal ini menunjukkan bahwa pupuk organik memeliki manfaat yang baik terhadap tumbuhan dan tanah. Namun, perlu dikatahui bahwa peranan bahan organik ada yang bersifat langsung terhadap tanaman, tetapi sebagian besar memengaruhi tanaman melalui perubahan sifat dan ciri tanah [13]. Hal tersebut karena menurut Lusiana dan Linda [14] menyatakan bahwa didalam urin hewan ternak yaitu sapi dan kambing mengandung zat pengatur tumbuh alami golongan auksin, sehingga 
pemberian biourin yang berasal dari urin kambing membuat berat akar dengan penambahan biourin lebih tinggi dibandingkan tanpa penambahan apapun.

Tabel. 2. Tanggapan peserta terhadap pelatihan yang diikuti

\begin{tabular}{|c|c|c|c|}
\hline & & \multicolumn{2}{|c|}{ Persentase (\%) } \\
\hline No & Komponen Pertanyaaan & Ya & Tidak \\
\hline 1 & Apakah saudara merasa senang mengikuti pelatihan ini? & 100 & 0 \\
\hline 2 & $\begin{array}{l}\text { Apakah saudara merasakan mendapat pengetahuan/ wawasan } \\
\text { baru dalam pelatihan ini? }\end{array}$ & 100 & 0 \\
\hline 3 & Apakah saudara merasakan manfaatnya dari pelatihan ini? & 60 & 40 \\
\hline 4 & $\begin{array}{l}\text { Apakah bahan-bahan yang digunakan pada pelatihan ini tersedia } \\
\text { banyak di lingkungan saudara? }\end{array}$ & 100 & 0 \\
\hline 5 & $\begin{array}{l}\text { Apakah saudara berkeinginan untuk mempraktekkan hasil } \\
\text { pelatihan ini? }\end{array}$ & 100 & 0 \\
\hline 6 & $\begin{array}{l}\text { Apakah ada keinginan saudara untuk mendapat pelatihan yang } \\
\text { lain? } \\
\text { Jika saudara menjawab "YA" pelatihan apa yang saudara } \\
\text { inginkan,sebutkan ........................ }\end{array}$ & 100 & 0 \\
\hline & Rata-rata & 93,3 & 6,67 \\
\hline
\end{tabular}

Berdasarkan angket tanggapan pada Tabel 2 diketahui bahwa pada poin 1 masayarakat antusias dalam mengikuti kegiatan pengabdian ini. Hal yang sama pada poin 2 menunjukkan bahwa respon masyararakat merasa mendapatkan pengetahuan baru dengan rata-rata $100 \%$. Poin 4, poin 5 dan poin 6 juga menunjukkan bahwa rata-rata respon masyarakat adalah $100 \%$. Hal ini didukung dengan bahan-bahan yang digunakan dalam pengabdian ini merupakan bahanbahan yang spesifik dan mudah ditemukan di masyarakat. Adanya bahan yang mudah diperoleh, dapat memotivasi masyarakat desa Cangkring untuk mebuat dan mengembangkan pupuk kompos organik dengan bantuan biourine. Poin 3 menunjukkan hasil yang rendah yaitu masayarakat yang merasakan manfaat pada pengabdian ini adalah $60 \%$. Berikut ini disajikan Gambar pada saat penyuluhan pemanfaatan limbah organik menjadi kompos dengan bantuan biourine.

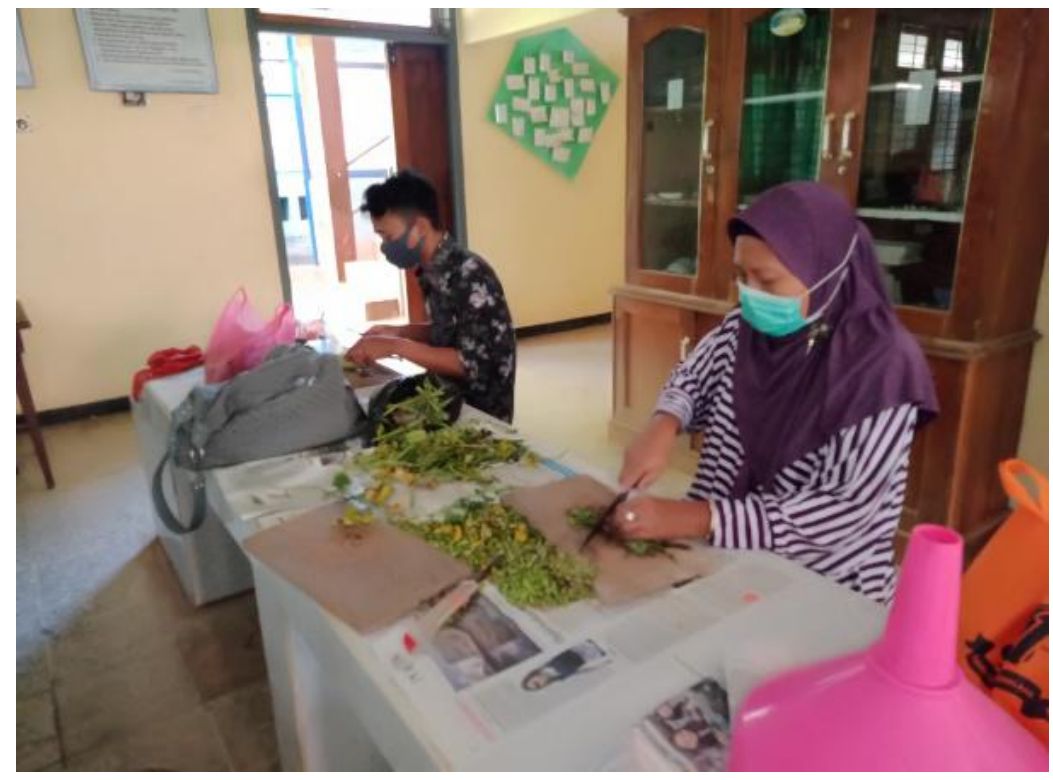

Gambar 1. Proses Perajangan Bahan-Bahan Organik (Mawartiningsih, Cintamulya \& Wulandari 2020) 


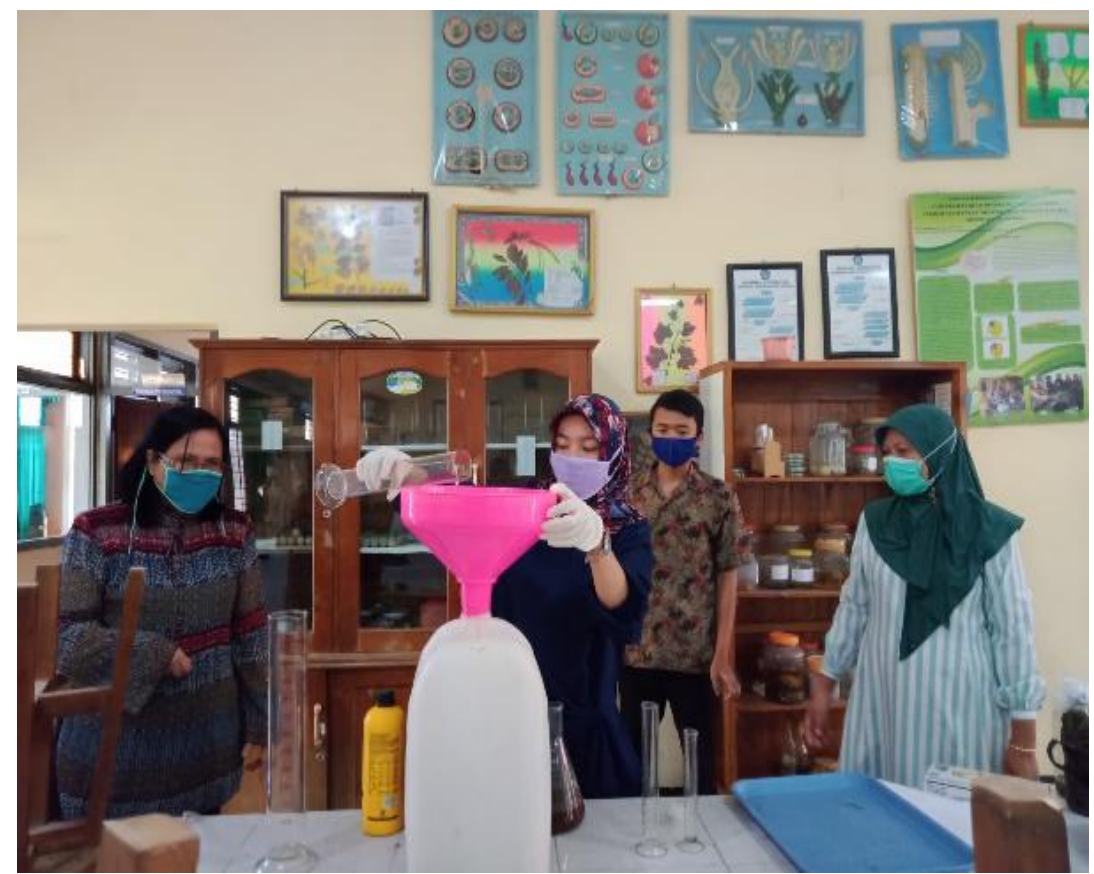

Gambar 2. Proses Pembuatan Biourine

(Mawartiningsih, Cintamulya \& Wulandari 2020)

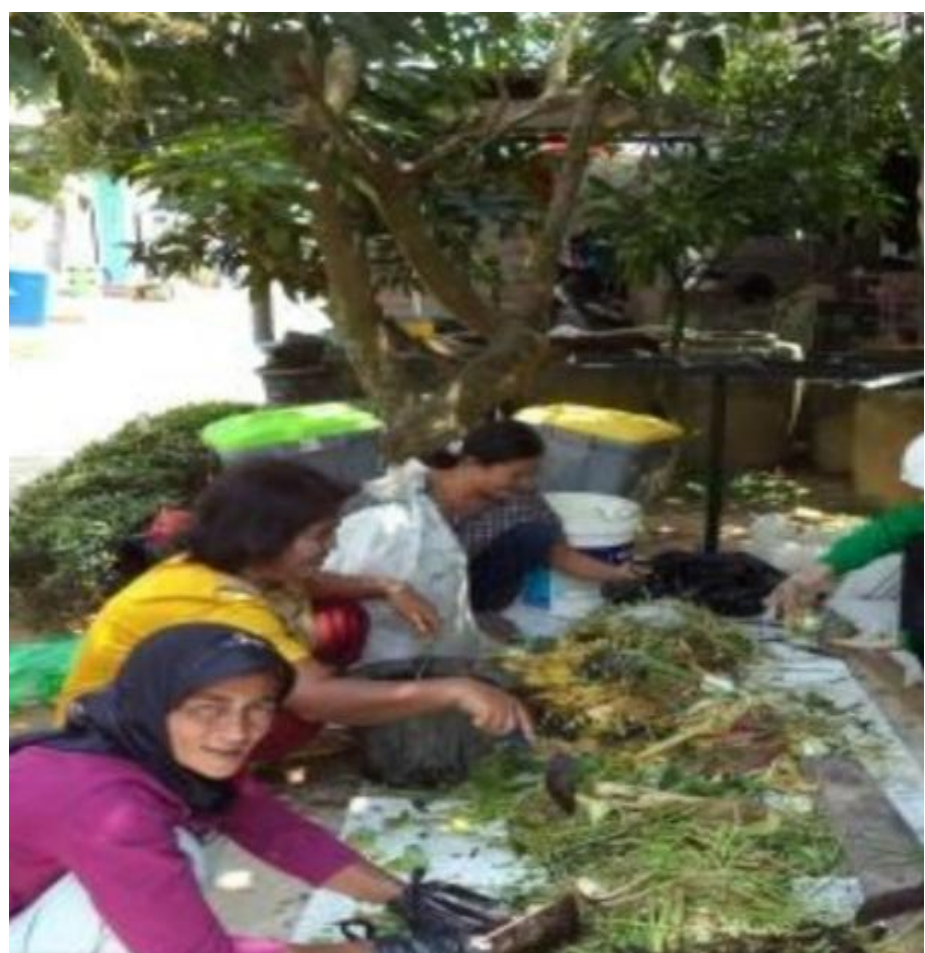

Gambar 3. Proses Pembuatan Biourine Oleh Masyarakat (Mawartiningsih, Cintamulya \& Wulandari 2020) 


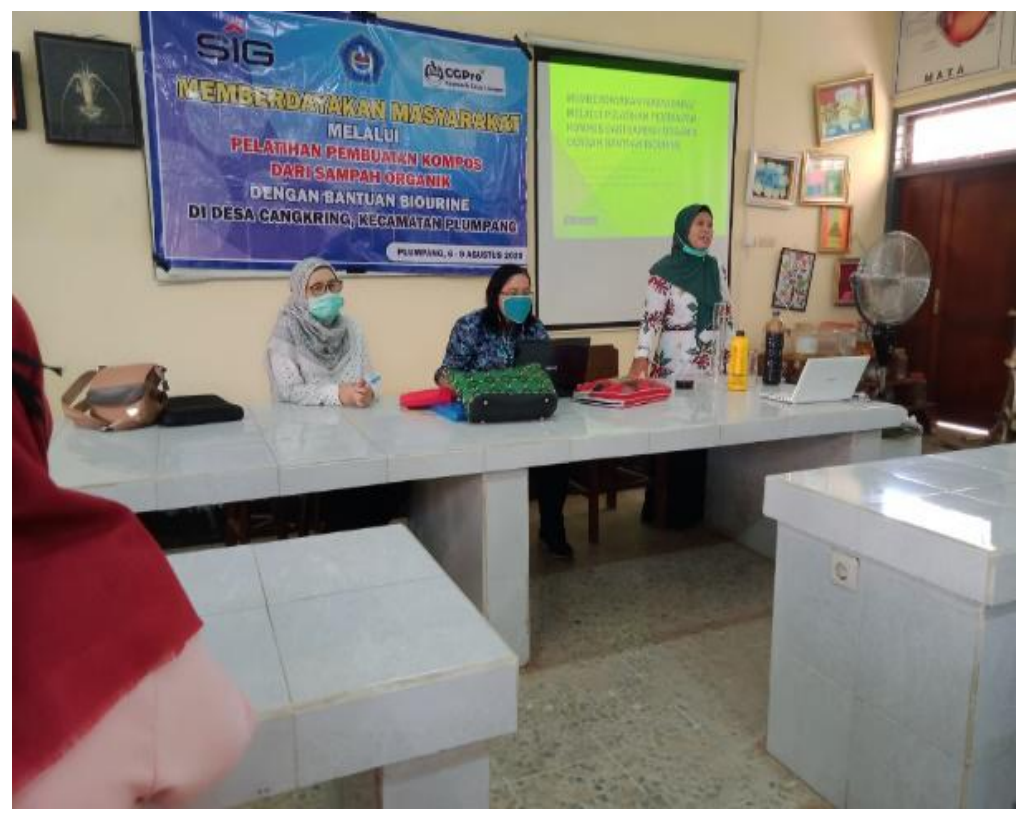

Gambar 4. Penyuluhan Dan Praktik Pembuatan Kompos Organik (Mawartiningsih, Cintamulya \& Wulandari 2020)

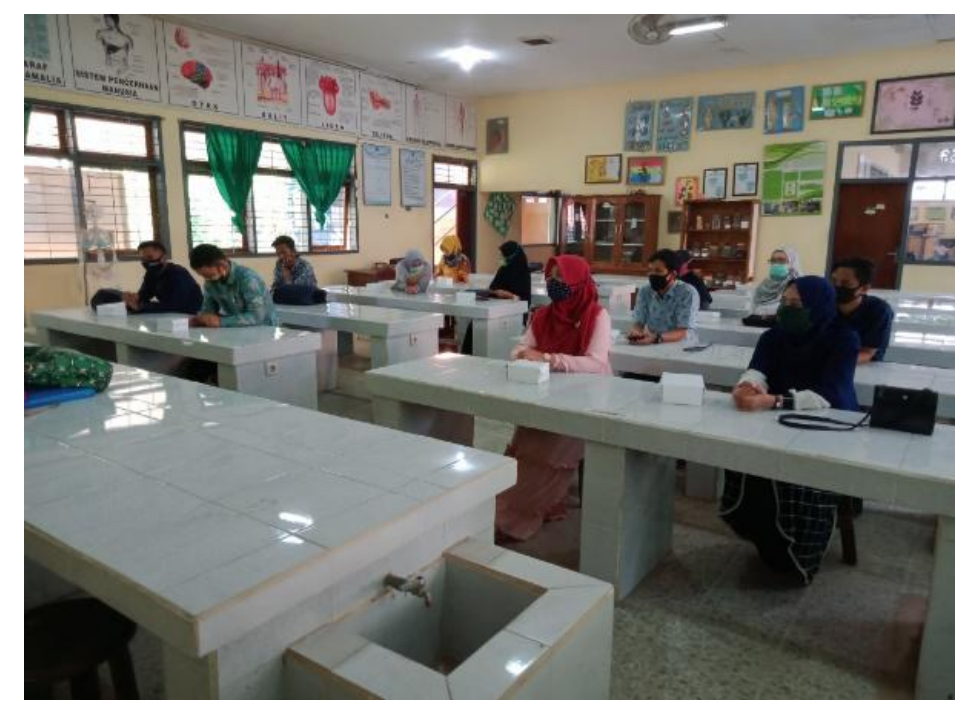

Gambar 5. Peserta Penyuluhan Pemanfaatan Limbah Organik Menjadi Kompos dengan Bantuan Biourine

(Mawartiningsih, Cintamulya \& Wulandari 2020)

Gambar 1 dan Gambar 2 merupakan tahapan pembuatan biourine yang dmulai dari proses perajangan, pencampuran bahan dan dilanjutkan dengan proses fermentasi. Gambar 3 merupakan implementasi pembuatan biourine oleh masyarakat Desa Cangkring Kecamatan Plumpang Kabupaten Tuban sedangkan Gambar 5 merupakan kegiatan awal penyuluhan dan penjelasan materi tentang pentingnya penggunaan biourine.Menurut Sungguh [15], bahwa fermentasi adalah penguraian unsur organik kompleks terutama karbohidrat untuk menghasilkan energi melalui reaksi enzim yang dihasilkan oleh mikroorganisme, yang biasanya terjadi dalam keadaan anaerob dan diiringi dengan pembebasan gas, hal ini bertujuan untuk menekan pertumbuhan mikroba pathogen agar proses degradasi berjalan dengan baik. Pupuk 
cair dari urine sapi sebelum fermentasi memiliki bau menyengat sedangkan sesudah mengalami fermentasi bau kurang menyengat.

Nitrogen dibutuhkan mikroba untuk pertumbuhan dan fungsi yang normal. [16] menambahkan semakin tinggi unsur $\mathrm{N}$, maka mikroba akan menggunakannya sebagai nutrisi untuk mensintesis protein sehingga pengomposan berjalan cepat. Waktu optimum dalam proses pengomposan yaitu pada minggu kedua. Hal ini diduga karena pada fase awal (inokulasi bakteri ke sampah) mikroba masih menyesuaikan diri dan melakukan metabolisme sehingga aktivitasnya meningkatkan ukuran sel. Selanjutnya sel menggunakan karbon sebagai makanan dan memperbanyak diri. Penguraian semakin baik dengan meningkatnya kadar N kompos. Kemudian mikroba mencapai kesetimbangan [17].

Selain Penguraian bahan organik karena adanya aktivitas bakteri seperti asam laktat, asam asetat. Asam-asam organik berasal dari penguraian karbohidrat, protein dan lemak. Penguraian bahan organik karena adanya aktivitas bakteri asam laktat yang menghasilkan asam seperti asam laktat dan asetat. Asam-asam organik yang diperoleh dari penguaraian karbohidrat, protein dan lemak [18]. pH merupakan faktor penting karena berpengaruh terhadap ketersediaan mineral yang dibutuhkan oleh tumbuhan dan salah satu faktor yang mempengaruhi aktivitas mikroorganisme didalam media penguraian bahan organik adalah $\mathrm{pH}$.

\section{Kesimpulan}

Berdasarkan tanggapan peserta pelatihan mengenai bahan yang digunakan dalam pelatihan banyak tersedia di lingkungan tempat tinggal mereka,terutama bahan EM4,tetapi mereka tidak tahu penggunaannya.Keunggulan pelatihan ini,kompos dari sampah organik dengan bantuan biourine dapat mempercepat pertumbuhan tanaman dan juga pupuk ini ramah lingkungan.Namun pupuk ini memiliki kekurangan yaitu proses pembuatanya membutuhkan waktu yang lama.Untuk kedepannya diharapkan para petani lebih banyak menggunakan pupuk kompos dengan biourine.Selain itu pupuk kompos dengan biourine bisa diproduksi lebih banyak lagi.

\section{Ucapan Terima Kasih}

Terimakasih kepada PT Semen Indonesia melalui program CG Pro ini dan masyarakat desa Cangkring serta pihak-pihak yang membantu terlaksananya pengabdian masyarakat..

\section{Daftar Pustaka}

[1] E. Novita, A. Fathurrohman, and H. A. Pradana, "Pemanfaatan Kompos Blok Limbah Kulit Kopi sebagai Media Tanam ( the Utilization of Coffee Pulp and Coffee Husk Compost Block as Growing Media )," J. AGROTEK, vol. 2, no. 2, pp. 61-72, 2018.

[2] BPPT, Data Status Lingkungan Hidup Daerah Sumatera Barat Tahun 2015. Sumatera Barat: BPPT, 2015.

[3] N. Yanqoritha, "Optimasi aktivator dalam pembuatan kompos organik dari limbah kakao," Mektek, vol. 15, no. 2, pp. 103-108, 2013.

[4] K. Mahmuda, Salundik, and P. D. M. H. Karti, "Penggunaan Mikroorganisme Lokal dari Berbagai Formula terhadap Kualitas Biourine Kambing Terfortifikasi," J. Ilmu Produksi Dan Teknol. Has. Peternak., vol. 8, no. 1, pp. 1-7, 2020, doi: 10.29244/jipthp.8.1.1-7.

[5] A. Meriatna, M., Suryati, S., \& Fahri, "Pengaruh Waktu Fermentasi dan Volume Bio Aktivator EM4 (Effective Microorganisme) pada Pembuatan Pupuk Organik Cair (POC) dari Limbah Buah-Buahan," J. Teknol. Kim. Unimal, vol. 7, no. 1, pp. 13-29., 2019.

[6] S. Aisyah, R. S. S. Aisyah, and I. E. Wijayanti, "Learning the Selvo E-Module To Stimulate Critical Thinking Skills Students,” JCER J. ..., vol. 3, no. 1, pp. 29-34, 2019. 
[7] S. Hadisuwito, Membuat Pupuk Kompos Cair. Jakarta.: AgroMedia., 2007.

[8] R. Samekto, Pupuk Kandang. Yogyakarta.: PT. Citra Aji Parama., 2006.

[9] M. M. Sutedjo, Pupuk dan Cara Pemupukan. Jakarta.: PT. Rineka Cipta., 1999.

[10] AZ.Nasution, Hukum Perlindungan Konsumen Di Indonesia. bandung: PT.Citra Aditya Bakti., 2014.

[11] A. I. Setiawan, Memanfaatkan Kotoran Ternak. Jakarta.: Penebar Swadaya, 2007.

[12] P. B. Utomo and J. Nurdiana, "Evaluasi Pembuatan Kompos Organik Dengan Menggunakan Metode Hot Composting,” J. Teknol. Lingkung., vol. 2, no. 1, pp. 28-32, 2018.

[13] Nurtitayani. Raihan S, "Pengaruh pemberian bahan organik terhadap N dan P tersedia tanah serta hasil beberapa varietas jagung di lahan pasang surut Sulfat masam.," Agrivita., vol. 2, no. 3, pp. 13-19, 2002.

[14] Mukarlina. Lusiana, Linda R, "Respon pertumbuhan stek batang sirih merah setelah direndam dalam urin sapi.," J. Protobiont, vol. 2, no. 2, pp. 157-160, 2013.

[15] A. Sungguh, Kamus Lengkap Biologi. Jakarta: Gaya Media Pratama, 1993.

[16] S. S. Indriani F, Sutrisno E, "Studi Pengaruh Penambahan Limbah Ikan pada proses Pembuatan Pupuk Cair dari Urin Sapi terhadap Kandungan Unsur Hara Makro (CNPK).," J. Pupuk Organik Cair, vol. 1, no. 1, pp. 139-144., 2013.

[17] Gunawan, Kusmiadi, and Prasetiyono, "Studi Pemanfaatan Sampah Organik Sayuran Sawi (Brassica juncea L.) dan Limbah Rajungan (Portunus pelagicus) Untuk Pembuatan Kompos Organik Cair," J. Pertan. Dan Lingkung., vol. 8, no. 1, pp. 37-47, 2015.

[18] U. Suriawiria, Mikrobiologi Air dan Dasar-Dasar Pengolahan Buangan Secara Biologis. Bandung: PT. Alumni. Bandung., 2003. 


\section{Afiliasi:}

Lilik Mawartiningsih ${ }^{(*)}$, Imas Cintamulya, Tabitha Sri Hartati Wulandari Program Studi Pendidikan Biologi Universitas PGRI Ronggolawe Tuban Jalan Manunggal No.61 Tuban Jawa Timur Indonesia.

E-mail : Lilik.mawar1901@gmail.com ${ }^{(*)}$, cintamulya66@gmail.com URL : https://unirow.ac.id 